\title{
CINKO TRŪKUMAS: PRIEŽASTYS IR SIMPTOMAI
}

\author{
Agnè Norbutaitė \\ Vilniaus universiteto Medicinos fakultetas
}

\begin{abstract}
Raktažodžiai: cinkas, cinko trūkumas, priežastys, simptomai.

\section{Santrauka}

Cinkas yra žmogaus organizmui būtinas mikroelementas, kuris dalyvauja įvairiose fiziologinèse reakcijose, ypač svarbus augimui, imuninei sistemai, audiniu vientisumo palaikymui ir žaizdu gijimui. Cinko trūkumas dažniausiai atsiranda dèl nepakankamo jo gavimo su maistu, kitos galimos priežastys yra sutrikusi jo absorbcija, išaugęs poreikis arba padidejęę netekimas. Šio mikroelemento trūkumas pasireiškia virškinamojo trakto simptomais, odos pokyčiais, sulètejusiu žaizdų gijimu, imuninių funkcijų sutrikimu ir reprodukcinès sistemos pažeidimais. Tyrimo tikslas - išanalizuoti ir apibendrinti mokslinių publikacijų duomenis apie cinko trūkumo priežastis ir jo sukeliamus simptomus.
\end{abstract}

\section{Ivadas}

Cinko randama visuose žmogaus kūno audiniuose ir skysčiuose, daugiausia jo yra skeleto raumenyse ir kauluose, šiek tiek mažiau odoje ir kepenyse. Cinkas dalyvauja ịvairiose fiziologinèse reakcijose ir yra ypač svarbus augimui, imuninei sistemai, audinių vientisumo palaikymui ir žaizdų gijimui [1]. Didžiausias cinko poreikis yra ankstyvojoje paauglystėje, kai vyksta spartus kaulų augimas. Didesnis cinko poreikis nustatytas kūdikiams, vaikams, nėščiosioms ir maitinančioms moterims bei pagyvenusiems žmonèms [2]. Šio mikroelemento atsargos nekaupiamos organizme, todèl jo būtina nuolat gauti su maistu [1]. Pagrindiniai cinko turintys maisto šaltiniai yra žuvis ir mèsa [3]. Skaičiuojama, kad cinko trūkumo paplitimas gali siekti iki 17 proc. populiacijos, o Pietų Azijos šalyse šis skaičius gali siekti net iki 30 procentų [4]. Cinko trūkumas varijuoja nuo lengvo, kurio simptomų galima nepastebėti, iki sunkaus, kuriam būdingi akivaizdūs klinikiniai požymiai [1]. Cinko perteklius pasitaiko labai retai, tačiau reikia prisiminti, kad cinkas yra toksiškas ląstelèms, ypač neuronams, o ūminis apsinuodijimas cinku gali paveikti kvėpavimo bei virškinimo sistemas, sukelti pykinimą, vėmimą, apetito stoką, pilvo ir galvos skausmus, todèl svarbu palaikyti optimalų cinko kiekị organizme [5].

Tyrimo tikslas - išanalizuoti ir apžvelgti naujausius mokslinius šaltinius apie cinko poveikị organizmui, jo trūkumo priežastis ir sukeliamus simptomus.

\section{Tyrimo medžiaga ir metodai}

Literatūros šaltinių paieška buvo vykdoma kompiuterinèse bibliografinèse medicinos duomenų bazèse PubMed, Google Scholar, Medscape. Naudoti raktažodžiai ir jų deriniai: zinc deficiency, causes, symptoms. İ apžvalgą įtrauktos 2015-2021 metų mokslinès publikacijos anglų kalba. Atrinkti, išanalizuoti ir apibendrinti 7 straipsniai.

\section{Tyrimo rezultatai}

Priežastys. Cinko trūkumas gali atsirasti dèl nepakankamo jo gavimo, padidejusio poreikio, sutrikusios absorbcijos virškinamajame trakte (pvz., sergant Krono liga, trumposios žarnos sindromu, igimtu enteropatiniu akrodermatitu) $[1,4]$. Trūkumo priežastis gali būti ir padidèjęs cinko išsiskyrimas per virškinamajj̨ traktą, su šlapimu ir per odą (ypač daug cinko netenkama esant odos nudegimų, sergant infekcinèmis ligomis, atliekant hemodializę, ivvykus hemolizei, viduriuojant, vartojant alkoholị ir diuretikus) $[3,4]$. Pati dažniausia cinko trūkumo priežastis visame pasaulyje yra per mažas cinko kiekis, gaunamas su maistu, arba didelis fitatų kiekis maiste, kadangi jie suriša cinką ir taip sutrikdo jo pasisavinimą $[1,4]$. Kai suvartojamo cinko kiekis sumažèja, kurị laiką homeostazès mechanizmai išlaiko normalią cinko koncentraciją plazmoje, bet vèliau pasireiškia trūkumo simptomai [1].

Simptomai. Cinkas dalyvauja daugelyje organizmo reakcijų, todèl jo trūkumas gali pažeisti ne vieną organų sistemą ir pasireikšti ịvairiais simptomais. Vieni iš dažniausių požymių, kuriuos nurodo pacientai, yra sumažèjęs apetitas, sutrikęs skonio jutimas ir uosle $[1,4]$. Gali pasireikšti viduriavimas, kurio metu prarandama dar daugiau cinko [1].

Cinko trūkumas neretai sukelia ir ịvairius odos pažeidimus, tokius kaip alopecija ar dermatitas, kuris dažniausiai paveikia perioralinę, perianalinę ir galūnių periferinių sričių 


\section{6}

odą, jam būdingas pūslelinis bèrimas [6,7]. Gali atsirasti ir nagų distrofija bei paronichija [4]. Dažnas šio mikroelemento trūkumo simptomas yra sulètejęs žaizdų gijimas [7]. Reprodukcinejje sistemoje cinko trūkumas gali būti susijęs hipogonadizmu ir jo komplikacijomis, įskaitant sumažèjusi plazmos testosterono kiekị ir nevaisingumą $[1,4]$. Su šio mikroelemento trūkumu siejamas augimo sulettejimas ir sumažèjusi raumenų jèga $[1,6]$. Centrinèje nervų sistemoje (CNS) gali pasireikšti emocijų labilumas, psichiatriniai sutrikimai ir fotofobija [4]. Kai kurie atlikti tyrimai nurodo ir galimą cinko sumažejimo ịtaką aterosklerozei, širdies bei kraujagyslių ligų rizikai ir vežzio vystymuisi, tačiau tai patvirtinti reikalingi tolesni tyrimai [5]. Kadangi cinkas dalyvauja imuninès sistemos reakcijose, jo trūkumas gali sutrikdyti šios sistemos funkcijas ir padidinti ịvairių infekcijų riziką [4]. Cinko trūkumas nèštumo metu gali būti susijęs su neišnešiotumu, komplikuotu gimdymu, mažu gimimo svoriu, igimtomis anomalijomis, smegenų funkcijos sutrikimais po gimimo ir sutrikusia kognityvinių funkcijų raida [1].

\section{Išvados}

1. Cinko trūkumas atsiranda dèl nepakankamo jo gavimo, sutrikusios jo absorbcijos, išaugusio poreikio arba padidejjusio netekimo.

2. Cinko trūkumas dažniausiai pasireiškia virškinamojo trakto simptomais, odos bėrimu, alopecija, sulètejusiu žaizdų gijimu, padidèjusia infekcijų rizika, augimo sulètèjimu ir reprodukcinès funkcijos sutrikimais.

3. Cinko trūkumas nèštumo metu gali turèti įtakos vaisiaus anomalijoms ir nèštumo bei gimdymo komplikacijoms.

\section{Literatūra}

1. Livingstone C. Zinc: physiology, deficiency, and parenteral nutrition. Nutr Clin Pract 2015;30(3):371-82. https://doi.org/10.1177/0884533615570376

2. Kogan S, Sood A, Garnick MS. Zinc and Wound Healing: A Review of Zinc Physiology and Clinical Applications. Wounds 2017;29(4):102-6.

3. Almohanna HM, Ahmed AA, Tsatalis JP, Tosti A. The Role of Vitamins and Minerals in Hair Loss: A Review. Dermatol Ther (Heidelb). 2019;9(1):51-70.

https://doi.org/10.1007/s13555-018-0278-6
4. Maxfield L, Crane JS. Zinc Deficiency. StatPearls Publishing 2021. http://www.ncbi.nlm.nih.gov/books/NBK493231/

5. Pan Z, Choi S, Ouadid-Ahidouch H, Yang J-M, Beattie JH, Korichneva I. Zinc transporters and dysregulated channels in cancers. Front Biosci (Landmark Ed) 2017;22:623-43. https://doi.org/10.2741/4507

6. DiBaise M, Tarleton SM. Hair, Nails, and Skin: Differentiating Cutaneous Manifestations of Micronutrient Deficiency. Nutrition in Clinical Practice 2019;34(4):490-503.

https://doi.org/10.1002/ncp.10321

7. Ogawa Y, Kinoshita M, Shimada S, Kawamura T. Zinc and Skin Disorders. Nutrients 2018;10(2).

https://doi.org/10.3390/nu10020199

\section{ZINC DEFICIENCY: CAUSES AND SYMPTOMS}

\section{A. Norbutaitė}

Keywords: zinc, zinc deficiency, causes, symptoms.

Summary

Zinc is a trace element found throughout the human body and involved in a variety of physiological reactions. It is required for growth, normal functioning of the immune system, maintaining tissues and wound healing. Zinc deficiency is usually caused by inadequate intake with food. Other possible causes include reduced absorption, increased demand or increased losses. Deficiency of this trace element manifests itself by gastrointestinal symptoms, skin damage, delayed wound healing, immune dysfunction and changes in reproductive system. The aim of this study is to analyze and summarize the data of scientific publications on the causes of zinc deficiency and its symptoms.

Conclusions. 1. Zinc deficiency results from inadequate intake, impaired absorption, increased demand or increased losses. 2. Zinc deficiency is most commonly associated with gastrointestinal symptoms, skin rash, alopecia, delayed wound healing, increased risk of infections, growth retardation and reproductive dysfunction. 3. Zinc deficiency in pregnant women may have influence on the development of fetal abnormalities. It might also cause complications during pregnancy and childbirth.

Correspondence to: agnenorb@gmail.com

Gauta 2021-05-19 